\title{
Effect of different dosage and administration schedules of folic acid on blood folate levels in a population of Honduran women of reproductive age
}

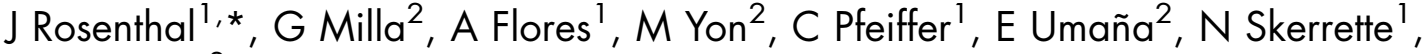 \\ F Barahona ${ }^{3}$ and The Cooperative Folic Acid Research Groupt \\ National Center on Birth Defects and Developmental Disabilities, Centers for Disease Control and Prevention, \\ 1600 Clifton Rd, MS E-86, Atlanta, GA 30333, USA: ${ }^{2}$ The Healthy Children Foundation, San Pedro Sula, \\ Honduras and Newton, MA, USA: ${ }^{3}$ Secretaria de Salud, Tegucigalpa, Honduras
}

Submitted 15 March 2007: Accepted 6 March 2008: First published online 22 April 2008

\begin{abstract}
Background: Observational studies and clinical trials have shown conclusive evidence that periconceptional folic acid supplementation prevents up to $70 \%$ of neural tube defects (NTD). The Honduran government wanted to implement a supplementation programme of folic acid but needed to assess the relative effects of two dosages of folic acid.

Objective: To determine the effect of two dosages of folic acid on blood folate levels in Honduran female factory workers aged 18 to 49 years.

Design: This was a randomized, double-blind control supplementation trial conducted in Choloma, Honduras. A total of 140 eligible women were randomly assigned to two dosage groups and followed up for 12 weeks. One group received a daily dosage of $1 \mathrm{mg}$ folic acid and the other a once weekly dosage of $5 \mathrm{mg}$. Serum folate and red blood cell folate levels were determined by radioassay at baseline, 6 weeks and 12 weeks.

Results: Serum folate levels increased from $6 \cdot 3(\operatorname{SE} 0 \cdot 2)$ to $14.9(\operatorname{se~} 0 \cdot 6) \mathrm{ng} / \mathrm{ml}$ $(P<0 \cdot 0001)$ in women assigned to the $1 \mathrm{mg} / \mathrm{d}$ group and from $6 \cdot 9(\operatorname{se} 0 \cdot 3)$ to $10 \cdot 1$ $(\mathrm{sE} 0 \cdot 4) \mathrm{ng} / \mathrm{ml}(P<0 \cdot 0001)$ in those assigned to the $5 \mathrm{mg}$ /week group. Red blood cell folate concentrations also increased significantly in both groups, albeit more slowly. Educational level, age and BMI were not associated with the changes in serum and red blood cell folate levels during the supplementation period. However, a differential effect on serum folate levels by dosage group and time was observed.

Conclusions: Although both folate supplementation regimens increased serum and red blood cell folate levels significantly among the women studied, blood folate levels that are considered to be protective of NTD were reached faster with the daily dosage of $1 \mathrm{mg}$ folic acid.
\end{abstract}

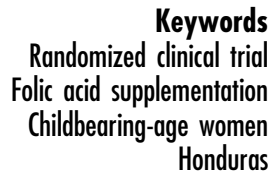

Folic acid supplementation

Honduras
Neural tube defects (NTD) are among the most frequent congenital malformations contributing to infant mortality and serious disability ${ }^{(1-4)}$. In Central America, information on the prevalence of NTD is scarce except for Costa Rica, Guatemala and Honduras, where prevalence rates

$\uparrow$ The Cooperative Folic Acid Research Group: Gayle Milla, Miguel Yon, Edgar Umaña, Stephanie Dodson and David Dodson (Project Healthy Children); Jorge Rosenthal, Alina Flores, Joe Mulinare, Jaime Frías, Christine Pfeiffer, Owen Devine, Nyasha Skerrette, Coleen Boyle and Jose Cordero (Centers for Disease Control and Prevention); Fidel Barahona, Elias Lizardo and Merlín Fernández (Ministerio de Salud de Honduras); José Samara, Roberto Recinos and María Elena Zacarías (Grupo Betesda); Xiomara Wu and Carla García (Grupo Kattan); James Rosa (NOW Foods) between 6/10 000 and 26/10 000 have been reported ${ }^{(5-8)}$. In these countries, NTD coupled with congenital heart defects constitute $40 \%$ of all causes of infant mortality ${ }^{(6)}$.

Observational studies and clinical trials have shown conclusive evidence that periconceptional folic acid supplementation prevents up to $70 \%$ of NTD $^{(9-12)}$. The level of effectiveness likely depends on the population's folate levels and the local prevalence of NTD ${ }^{(13-15)}$.

In 2002, Central American countries implemented a resolution to fortify wheat flour with $1.8 \mathrm{mg}$ folic acid/ $\mathrm{kg}^{(16)}$. Although fortification of wheat flour with folic acid has been mandatory in Honduras since January 2003, no monitoring system is in place to determine whether or not 
this fortification is done properly. In addition, consumption of wheat flour products in Honduras is low, as the main staples are rice, corn and beans ${ }^{(17)}$. Furthermore, although the Honduran Ministry of Health approved a periconceptional folic acid supplementation programme among women of childbearing age in February 2005, it has not been implemented. The Honduran government wanted to assess the efficacy of folic acid supplementation at a daily dose of $1 \mathrm{mg} v$. a weekly dose of $5 \mathrm{mg}$ to revise the national health policy. To address this question, we conducted a randomized controlled trial to compare the efficacy of the two regimens.

\section{Methods}

\section{Target population}

The study was conducted in Choloma, a city in north-west Honduras with a population of 190000 in $2005^{(18)}$. The city has several large assembly factories ('maquilas'). Staff held an information fair for all female workers aged 18 to 49 years in one of the maquilas willing to participate and, after explaining the purpose and content of the study, invited them to participate in the 12-week trial. The study protocol was approved by the Western Regional Institutional Review Board in Honduras and the Centers for Disease Control and Prevention (CDC) Institutional Review Board in Atlanta, Georgia, USA.

\section{Screening procedures}

Women who enrolled filled out a standardized questionnaire, which included the collection of demographic information, length of employment at the factory, place of origin, date of birth, level of education, reported medical history including pregnancy status and history, current medications and vitamin consumption. Women were excluded if they were younger than 18 years or older than 49 years, if they had been employed at the maquila for 6 months or less, if they were reported to be pregnant at the time of the interview, or if they had consumed a supplement containing folic acid during the three months prior to the study. Also excluded from the study were women who reported having had a previous pregnancy with a birth defect; those who had a chronic disease such as cancer, diabetes or chronic diarrhoea; and those who were taking medications that interfere with folic acid metabolism, including anticonvulsant drugs and folic acid antagonists. At the time of enrolment, blood was drawn to assess $\mathrm{Hb}$ levels and women with levels $<12 \mathrm{mg} / \mathrm{dl}$ were excluded and referred to the maquila clinic for diagnosis and treatment. From the volunteers who remained in the study, we obtained a second blood sample to determine vitamin $\mathrm{B}_{12}$ and folate status. Women who were found to be vitamin $\mathrm{B}_{12}$-deficient $(<200 \mathrm{pg} / \mathrm{ml})$ or who had folate levels $<2 \mathrm{ng} / \mathrm{ml}$ were excluded from participation and referred to the factory physician for diagnosis, treatment and follow-up.

\section{Study design}

The study was designed as a randomized, double-blind controlled supplementation trial to assess in a 12-week period the impact of two dosage levels of folic acid on blood folate levels not at steady state among women of childbearing age. Selection of the duration of the study was based on taking into consideration comparability with other efficacy studies, working schedules for participating volunteers and the fact that longer periods might have decreased compliance. Sample size was determined using the criteria that a true difference of $5 \mathrm{ng} / \mathrm{ml}$ should be detected with a power of $95 \%$ using a two-tailed test at a significance level of $0 \cdot 05$. Under these criteria, we determined that each final dosage group should be composed of fifty subjects. This sample size was increased to about seventy subjects to protect against attrition of up to $30 \%$. A randomization program was used to allocate volunteers into the two groups ${ }^{(19)}$. The trial was conducted between April and June 2005. During workdays, folic acid pills were administered to the study subjects by two factory nurses. Women assigned to the $5 \mathrm{mg}$ /week group were given the folic acid supplement on Wednesdays and received a placebo on the other days of the week. Each Friday, participants took home the pills corresponding to Saturday and Sunday, and on Mondays the nurses documented if they had been consumed. There was no penalty for forgetting to take the pill. The $1 \mathrm{mg}, 5 \mathrm{mg}$ and placebo pills were of the same colour and size, and neither the authors nor the health staff or volunteers were aware of the subject's dose category until the study was completed.

\section{Biochemical analyses}

At baseline, midpoint (6 weeks) and endpoint (12 weeks), venous blood samples were collected from all participants after an overnight fast. Women receiving daily and weekly doses of folic acid had their blood samples drawn $1 \mathrm{~d}$ and $5 \mathrm{~d}$ after the last pill was taken, respectively. Blood samples were allowed to clot at room temperature for $30 \mathrm{~min}$ to $2 \mathrm{~h}$; then serum was separated from the red cells by centrifugation and stored frozen at $\leq-40^{\circ} \mathrm{C}$ until analysis. EDTA whole blood was diluted 1:11 with ascorbic acid $(10 \mathrm{~g} / \mathrm{l})$ and stored frozen at $\leq-40^{\circ} \mathrm{C}$ until analysis. Frozen samples were shipped on dry ice to the CDC laboratory where biochemical analyses were conducted. Total folate and vitamin $\mathrm{B}_{12}$ in serum and total folate in whole blood were measured by a radioassay $^{(20)}$. An aliquot of serum or 1:11 diluted whole blood (with ascorbic acid $10 \mathrm{~g} / \mathrm{l}$ ) was combined with the tracers $\left[{ }^{125}\right.$ I]folate and $\left[{ }^{57} \mathrm{Co}\right]$ vitamin $\mathrm{B}_{12}$, which were then boiled to inactivate endogenous folate-binding proteins, and the various forms of vitamin $\mathrm{B}_{12}$ were converted to cyanocobalamin. After cooling, the solution was combined with immobilized affinity-purified porcine intrinsic factor and folate-binding proteins, incubated for $1 \mathrm{~h}$ at room temperature, centrifuged, decanted, and the radioactivity associated with the pellet counted. Standard curves prepared by using 
the precalibrated folate/vitamin $\mathrm{B}_{12}$ standards in a human serum albumin base were used to determine the concentration of the folate and vitamin $\mathrm{B}_{12}$ in the patients' serum and whole blood.

\section{Statistical analyses}

Statistical analyses were conducted using the SAS for Windows statistical software package version $9 \cdot 13$ (SAS Institute Inc., Cary NC, USA) ${ }^{(19)}$. Baseline characteristics in the two groups were compared using the $t$ test for continuous variables and the $\chi^{2}$ test for categorical variables. We investigated the effects of the supplemental dosage regimen using a generalized linear regression model (PROC MIXED procedure in SAS) ${ }^{(21)}$ of repeated measures analysis to determine if there were changes in serum and blood folate levels over time and (via interaction terms) whether over time trends were related to women's baseline age, education and BMI. All analyses were conducted based on the intention to treat, and $P$ values were two-sided. For the generalized regression model, we assumed the correlation matrix across time within subjects to be unstructured. Due to the tendency of the distribution of the observed data to be skewed to the right, the serum and red blood cell folate levels were transformed using the natural log prior to fitting the longitudinal model. Results are presented without transformation because they supported the same outcomes.

\section{Results}

The number of volunteers and participants are summarized in Fig. 1. Of the 288 women who volunteered, fortyseven were not eligible because they were pregnant, had been taking supplements with folic acid, suffered from chronic disease or had a previous pregnancy with a birth defect. An additional forty-six women were not eligible because they were found to be anaemic. Screening of the remaining 195 women for serum folate and vitamin $\mathrm{B}_{12}$ levels showed that an additional fifty were ineligible because of low folate or $\mathrm{B}_{12}$. This decreased the number of eligible volunteers to 145 . An additional five women were ineligible because they only worked $4 \mathrm{~d} /$ week. Thus, 140 women were enrolled and randomly assigned to a folic acid supplementation regimen of either $5 \mathrm{mg}$ once weekly or $1 \mathrm{mg}$ daily. Follow-up rates at the end of the study were fifty-eight out of seventy $(82 \cdot 9 \%)$ for the $5 \mathrm{mg}$ once weekly dosage group and fifty of out seventy (71.4\%) for the $1 \mathrm{mg}$ daily dosage group. Eleven volunteers in the $5 \mathrm{mg}$ /week group dropped out from the study because of the following reasons: four resigned from work, three became pregnant, one had low $\mathrm{B}_{12}$ and three did not want to continue in the trial. Among the women in the $1 \mathrm{mg} / \mathrm{d}$ group, eight dropped out because they resigned their positions, two were fired, five became pregnant, one had low $\mathrm{B}_{12}$, two had burning and discomfort, and two did not give any specific reason.

Both groups were similar at baseline in terms of age, height, weight, BMI, educational level, and $\mathrm{Hb}$ and vitamin $\mathrm{B}_{12}$ levels (Table 1 ).

\section{Effects on serum and red blood cell folate}

Baseline serum and red blood cell folate levels did not differ significantly between the two groups (Table 2). During the 12-week supplementation period, both dosage supplementation groups $(5 \mathrm{mg} /$ week and $1 \mathrm{mg} / \mathrm{d}$ ) resulted in a significant increase in serum folate; however, increases differed by dosage group. Among women assigned to the $5 \mathrm{mg} /$ week group, serum folate levels increased from $6.9(\operatorname{se} 0.4)$ to $10 \cdot 1($ SE 0.3$) \mathrm{ng} / \mathrm{ml}(P<$ 0.0001). Women assigned to the daily supplementation group $(1 \mathrm{mg} / \mathrm{d})$ increased their serum folate levels from

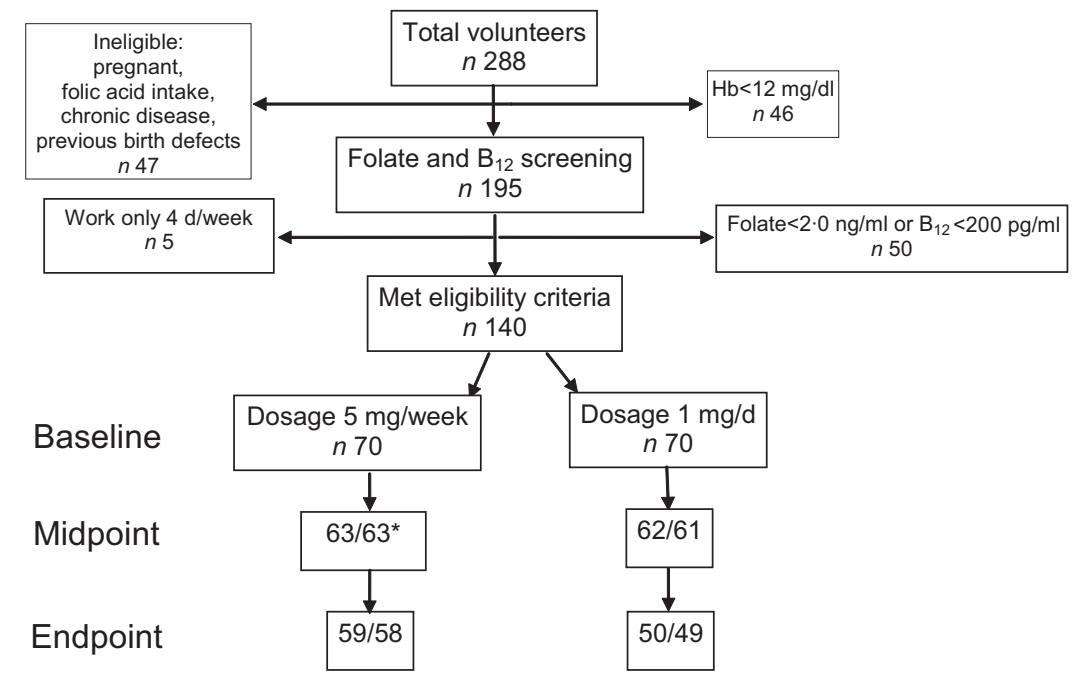

Fig. 1 Flow and follow-up of study participants: Honduras, 2005 ( ${ }^{*}$ number of women remaining in study/number of women with blood draws) 
Table 1 Characteristics of study participants by folic acid dosage and compliance status at baseline: Honduras, 2005

\begin{tabular}{|c|c|c|c|c|c|c|c|}
\hline \multirow[b]{3}{*}{ Characteristic } & \multicolumn{6}{|c|}{ Total population } & \multirow[b]{3}{*}{$P$ for difference } \\
\hline & \multicolumn{3}{|c|}{$5 \mathrm{mg} /$ week $(n 70)$} & \multicolumn{3}{|c|}{$1 \mathrm{mg} / \mathrm{d}(n 70)$} & \\
\hline & Mean & SE & Median & Mean & SE & Median & \\
\hline Age (years) & $26 \cdot 7$ & 0.9 & $26 \cdot 8$ & $26 \cdot 8$ & 0.5 & $26 \cdot 0$ & NS \\
\hline Education (years) & $7 \cdot 1$ & 0.4 & $6 \cdot 0$ & $7 \cdot 2$ & $0 \cdot 3$ & $6 \cdot 0$ & NS \\
\hline Weight $(\mathrm{kg})$ & $57 \cdot 7$ & $1 \cdot 3$ & $56 \cdot 4$ & $58 \cdot 7$ & 1.5 & $58 \cdot 0$ & NS \\
\hline Height (m) & 1.5 & 0.8 & 1.5 & 1.5 & 0.9 & 1.5 & NS \\
\hline $\operatorname{BMI}\left(\mathrm{kg} / \mathrm{m}^{2}\right)$ & $25 \cdot 0$ & $1 \cdot 3$ & $23 \cdot 7$ & $25 \cdot 3$ & 0.9 & $24 \cdot 7$ & NS \\
\hline $\mathrm{Hb}(\mathrm{mg} / \mathrm{dl})$ & $13 \cdot 2$ & 0.3 & $13 \cdot 1$ & $13 \cdot 3$ & 0.3 & $13 \cdot 2$ & NS \\
\hline \multirow{4}{*}{ Vitamin $B_{12}(p g / m l)$} & $319 \cdot 3$ & $13 \cdot 8$ & $289 \cdot 5$ & $355 \cdot 2$ & $17 \cdot 3$ & $326 \cdot 6$ & NS \\
\hline & \multicolumn{6}{|c|}{ Compliers } & \\
\hline & \multicolumn{3}{|c|}{$5 \mathrm{mg} /$ week $(n 58)$} & \multicolumn{3}{|c|}{$1 \mathrm{mg} / \mathrm{d}(n 50)$} & \\
\hline & Mean & SE & $\overline{\text { Median }}$ & Mean & $\mathrm{SE}$ & Median & \\
\hline Age (years) & $26 \cdot 8$ & 0.9 & $26 \cdot 0$ & $27 \cdot 6$ & 0.9 & $26 \cdot 7$ & NS \\
\hline Education (years) & $7 \cdot 1$ & 0.5 & $6 \cdot 0$ & 6.9 & 0.6 & $6 \cdot 0$ & NS \\
\hline Weight $(\mathrm{kg})$ & $57 \cdot 7$ & $1 \cdot 6$ & $56 \cdot 3$ & $58 \cdot 7$ & 1.5 & $56 \cdot 8$ & NS \\
\hline Height (m) & 1.5 & 0.8 & 1.5 & $1 \cdot 6$ & 0.9 & 1.5 & NS \\
\hline BMI $\left(\mathrm{kg} / \mathrm{m}^{2}\right)$ & $25 \cdot 3$ & 0.7 & 23.7 & $25 \cdot 2$ & 0.6 & $24 \cdot 7$ & NS \\
\hline $\mathrm{Hb}(\mathrm{mg} / \mathrm{dl})$ & $13 \cdot 1$ & 0.8 & $13 \cdot 0$ & $13 \cdot \overline{3}$ & $1 \cdot 2$ & $13 \cdot 2$ & NS \\
\hline \multirow[t]{4}{*}{${\text { Vitamin } B_{12}(p g / m l)}$} & $345 \cdot 3$ & $17 \cdot 3$ & $323 \cdot 5$ & $319 \cdot 2$ & $18 \cdot 3$ & $305 \cdot 6$ & NS \\
\hline & \multicolumn{6}{|c|}{ Non-compliers } & \\
\hline & \multicolumn{3}{|c|}{$5 \mathrm{mg} /$ week $(n 12)$} & \multicolumn{3}{|c|}{$1 \mathrm{mg} / \mathrm{d}(n 20)$} & \\
\hline & Mean & SE & Median & Mean & SE & Median & \\
\hline Age (years) & $25 \cdot 6$ & $1 \cdot 1$ & $25 \cdot 8$ & $24 \cdot 5$ & 1.5 & $24 \cdot 7$ & NS \\
\hline Education (years) & $6 \cdot 8$ & 0.6 & $6 \cdot 0$ & $6 \cdot 2$ & 0.3 & $6 \cdot 0$ & NS \\
\hline Weight $(\mathrm{kg})$ & $58 \cdot 0$ & 3.9 & $55 \cdot 2$ & $57 \cdot 8$ & $2 \cdot 4$ & $57 \cdot 7$ & NS \\
\hline Height (m) & 1.5 & $0 \cdot 1$ & 1.5 & 1.5 & $0 \cdot 1$ & 1.5 & NS \\
\hline $\operatorname{BMl}\left(\mathrm{kg} / \mathrm{m}^{2}\right)$ & $25 \cdot 8$ & 1.6 & $24 \cdot 2$ & $24 \cdot 8$ & $1 \cdot 1$ & $24 \cdot 2$ & NS \\
\hline $\mathrm{Hb}(\mathrm{mg} / \mathrm{dl})$ & $12 \cdot 9$ & $2 \cdot 4$ & $12 \cdot 8$ & $13 \cdot 0$ & $2 \cdot 3$ & $13 \cdot 2$ & NS \\
\hline Vitamin $B_{12}(p g / m l)$ & $281 \cdot 0$ & $26 \cdot 7$ & $236 \cdot 8$ & $333 \cdot 2$ & 31.9 & $319 \cdot 6$ & NS \\
\hline
\end{tabular}

Table 2 Serum folate and red blood cell folate levels of study participants at baseline, midpoint (6 weeks) and endpoint (12 weeks): Honduras, 2005

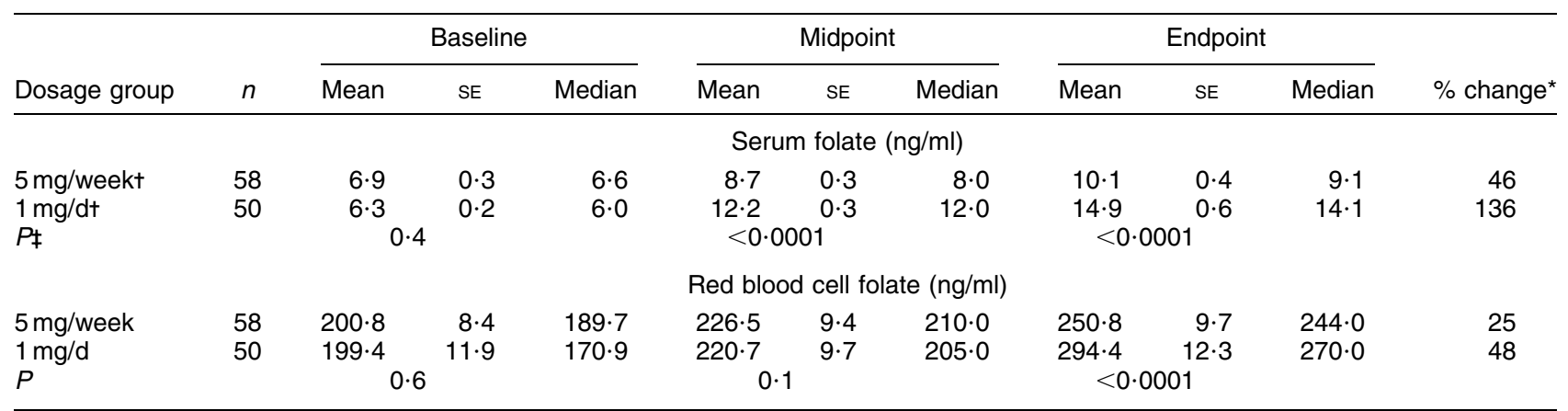

*Percentage increase from baseline to endpoint.

tMean values were significantly different at each time point (test for trend): $P<0.0001$.

$\ddagger$ Cross-sectional significance level of difference between mean values of $5 \mathrm{mg}$ and $1 \mathrm{mg}$ dosage at each time point.

$6 \cdot 3(\operatorname{se~} 0 \cdot 2)$ to $14.9(\operatorname{se~} 0 \cdot 6) \mathrm{ng} / \mathrm{ml}(P<0.0001)$. These folate levels at the endpoint were $46 \%$ and $136 \%$ higher than at baseline, respectively. Red blood cell folate concentrations also increased significantly in both groups, but at a slower rate: $25 \%$ and $48 \%$, respectively.

The magnitude of the increase in serum and red blood cell folate was influenced by the baseline quartile of serum and red blood cell folate levels and the folic acid dosage. Subjects in the lowest quartile of baseline serum and red blood cell folate $(<25$ th percentile) and receiving $1 \mathrm{mg}$ folic acid/d showed a larger increase in serum (230\%) and red blood cell folate (89\%) than did subjects receiving a single weekly dose of $5 \mathrm{mg}$ folic acid $(92 \%$ and $33 \%$, respectively) (Table 3 ). The difference in red 
Table 3 Serum folate and red blood cell folate levels of study participants by baseline quartile of serum and red blood cell folate levels and folic acid dosage regimen: Honduras, 2005

\begin{tabular}{|c|c|c|c|c|c|c|c|c|c|c|}
\hline \multirow[b]{2}{*}{ Dosage group } & \multirow[b]{2}{*}{ Baseline quartile } & \multirow[b]{2}{*}{$n$} & \multicolumn{2}{|c|}{ Baseline } & \multicolumn{2}{|c|}{ Midpoint } & \multicolumn{2}{|c|}{ Endpoint } & \multirow[b]{2}{*}{$\%$ change $^{*}$} & \multirow[b]{2}{*}{$P+$} \\
\hline & & & Mean & $95 \% \mathrm{Cl}$ & Mean & $95 \% \mathrm{Cl}$ & Mean & $95 \% \mathrm{Cl}$ & & \\
\hline & \multicolumn{10}{|c|}{ Serum folate $(\mathrm{ng} / \mathrm{ml})$} \\
\hline $5 \mathrm{mg} /$ week & 1st quartileł & 14 & $3 \cdot 8$ & $3 \cdot 5,4 \cdot 1$ & $6 \cdot 5$ & $5 \cdot 9,7 \cdot 1$ & $7 \cdot 3$ & $6 \cdot 4,8 \cdot 1$ & 92 & $<0.0001$ \\
\hline $1 \mathrm{mg} / \mathrm{d}$ & & 12 & \multicolumn{2}{|c|}{$0.06 \|$} & $11 \cdot 1$ & $\begin{array}{c}9 \cdot 6,12 \cdot 7 \\
0\end{array}$ & 0.004 & $9 \cdot 9,18 \cdot 4$ & 230 & $<0.0001$ \\
\hline $5 \mathrm{mg} /$ week & 2nd quartile & 15 & $5 \cdot 6$ & $5 \cdot 2,5 \cdot 9$ & $7 \cdot 9$ & $6 \cdot 8,8.9$ & $8 \cdot 8$ & $7 \cdot 9,9 \cdot 8$ & 57 & $<0.0001$ \\
\hline $1 \mathrm{mg} / \mathrm{d}$ & & 13 & $5 \cdot 6$ & $5 \cdot 5,5 \cdot 8$ & $11 \cdot 6$ & $10 \cdot 5,12 \cdot 7$ & $13 \cdot 7$ & $12 \cdot 2,15 \cdot 2$ & 145 & $<0.0001$ \\
\hline$P$ & & & \multicolumn{2}{|c|}{0.71} & \multicolumn{2}{|c|}{0.002} & \multicolumn{2}{|c|}{0.0005} & & \\
\hline $5 \mathrm{mg} /$ week & 3rd quartile & 14 & $7 \cdot 4$ & $7 \cdot 1,7 \cdot 8$ & $9 \cdot 3$ & $8 \cdot 4,10 \cdot 1$ & $10 \cdot 8$ & $9 \cdot 3,12 \cdot 2$ & 46 & 0.0008 \\
\hline $1 \mathrm{mg} / \mathrm{d}$ & & 12 & $6 \cdot 6$ & $6 \cdot 4,6 \cdot 8$ & $12 \cdot 0$ & $10 \cdot 7,13 \cdot 3$ & $16 \cdot 3$ & $13 \cdot 6,19 \cdot 0$ & 147 & $<0.0001$ \\
\hline$P$ & & & \multicolumn{2}{|c|}{$0.81^{0.4,0.0}$} & \multicolumn{2}{|c|}{0.006} & \multicolumn{2}{|c|}{0.005} & & \\
\hline $5 \mathrm{mg} /$ week & 4th quartile & 15 & $10 \cdot 5$ & $9 \cdot 5,11 \cdot 4$ & $11 \cdot 1$ & $9 \cdot 6,12 \cdot 5$ & $13 \cdot 5$ & $11 \cdot 7,15 \cdot 3$ & 29 & $0 \cdot 027$ \\
\hline $1 \mathrm{mg} / \mathrm{d}$ & & 13 & 8.5 & $7 \cdot 9,9 \cdot 0$ & $14 \cdot 0$ & $12 \cdot 8,15 \cdot 2$ & $15 \cdot 4$ & $13 \cdot 8,17 \cdot 1$ & 81 & $<0.0001$ \\
\hline \multirow[t]{2}{*}{$P$} & & & \multicolumn{2}{|c|}{0.003} & \multicolumn{2}{|c|}{0.019} & \multicolumn{2}{|c|}{0.15} & & \\
\hline & \multicolumn{10}{|c|}{ Red blood cell folate $(\mathrm{ng} / \mathrm{ml})$} \\
\hline $5 \mathrm{mg} /$ week & 1st quartile§ & 15 & $132 \cdot 4$ & $122 \cdot 4,142 \cdot 4$ & $156 \cdot 7$ & $143 \cdot 3,170 \cdot 2$ & $176 \cdot 3$ & $162 \cdot 2,190 \cdot 5$ & 33 & 0.0004 \\
\hline $1 \mathrm{mg} / \mathrm{d}$ & & 12 & $125 \cdot 5$ & $114 \cdot 1,136 \cdot 9$ & $168 \cdot 1$ & $152 \cdot 7,183 \cdot 5$ & $237 \cdot 3$ & $211 \cdot 1,263 \cdot 4$ & 89 & $<0.0001$ \\
\hline$P$ & & & \multicolumn{2}{|c|}{$\begin{array}{c}120.0 \\
0.55\end{array}$} & \multicolumn{2}{|c|}{0.36} & \multicolumn{2}{|c|}{0.002} & & \\
\hline $5 \mathrm{mg} /$ week & 2nd quartile & 14 & $175 \cdot 7$ & $170 \cdot 5,181 \cdot 0$ & $200 \cdot 6$ & $187 \cdot 3,214 \cdot 0$ & $226 \cdot 3$ & $213 \cdot 2,239 \cdot 4$ & 29 & $<0.0001$ \\
\hline $1 \mathrm{mg} / \mathrm{d}$ & & 13 & $160 \cdot 1$ & $157 \cdot 0,163 \cdot 3$ & $193 \cdot 6$ & $177 \cdot 9,209 \cdot 3$ & $254 \cdot 4$ & $228 \cdot 3,280 \cdot 5$ & 59 & $<0.0001$ \\
\hline$P$ & & & \multicolumn{2}{|c|}{0.011} & \multicolumn{2}{|c|}{0.34} & \multicolumn{2}{|c|}{0.09} & & \\
\hline $5 \mathrm{mg} /$ week & 3rd quartile & 15 & $208 \cdot 5$ & $201 \cdot 9,215 \cdot 1$ & $248 \cdot 7$ & $221 \cdot 9,275 \cdot 4$ & $259 \cdot 1$ & $243 \cdot 8,274 \cdot 4$ & 24 & $<0.0001$ \\
\hline $1 \mathrm{mg} / \mathrm{d}$ & & 13 & $198 \cdot 4$ & $189 \cdot 2,207 \cdot 6$ & $218 \cdot 2$ & $205 \cdot 1,231 \cdot 4$ & $296 \cdot 6$ & $276 \cdot 1,317 \cdot 1$ & 49 & $<0.0001$ \\
\hline$P$ & & & \multicolumn{2}{|c|}{0.14} & & 11 & & 02 & & \\
\hline $5 \mathrm{mg} /$ week & 4th quartile & 14 & $290 \cdot 8$ & $264 \cdot 8,316 \cdot 9$ & $305 \cdot 3$ & $271 \cdot 6,339 \cdot 0$ & $339 \cdot 4$ & $297 \cdot 9,381 \cdot 0$ & 17 & $0 \cdot 29$ \\
\hline $1 \mathrm{mg} / \mathrm{d}$ & & 12 & $298 \cdot 1$ & $246 \cdot 3,349 \cdot 9$ & $304 \cdot 2$ & $258 \cdot 8,349 \cdot 6$ & $397 \cdot 0$ & $341 \cdot 8,452 \cdot 2$ & 33 & 0.0193 \\
\hline$P$ & & & & $\cdot 38$ & & & & & & \\
\hline
\end{tabular}

${ }^{*}$ Percentage increase from baseline to endpoint.

tKruskal-Wallis test to compare dosage groups by baseline quartile and time point.

$\ddagger$ Serum folate $(\mathrm{ng} / \mathrm{ml}), 5 \mathrm{mg} /$ week dosage group: 1 st quartile, $<4.62 ;$ 2nd quartile, $\geq 4.62$ and $<6.64 ; 3$ rd quartile, $\geq 6.64$ and $<8.53 ; 4$ th quartile, $\geq 8.53$. Serum folate $(\mathrm{ng} / \mathrm{ml}), 1 \mathrm{mg} / \mathrm{d}$ dosage group: 1st quartile, $<5 \cdot 08 ;$ 2nd quartile, $\geq 5.08$ and $<5 \cdot 99 ; 3 \mathrm{rd}$ quartile, $\geq 5 \cdot 99$ and $<7 \cdot 28 ; 4$ th quartile, $\geq 7 \cdot 28$.

$\S$ Red blood cell folate $(\mathrm{ng} / \mathrm{ml}), 5 \mathrm{mg} /$ week dosage group: 1 st quartile, $<162 \cdot 00 ; 2$ nd quartile, $\geq 162 \cdot 00$ and $<189 \cdot 76 ; 3 \mathrm{rd}$ quartile, $\geq 189 \cdot 76$ and $<229 \cdot 71 ; 4$ th quartile, $\geq 229 \cdot 71$. Red blood cell folate $(\mathrm{ng} / \mathrm{ml}), 1 \mathrm{mg} / \mathrm{d}$ dosage group: 1 st quartile, $<150 \cdot 73 ; 2$ nd quartile, $\geq 150 \cdot 73$ and $<168 \cdot 59 ; 3 \mathrm{rd}$ quartile, $\geq 168 \cdot 59$ and $<219.03$; 4th quartile $\geq 219 \cdot 03$.

IIWilcoxon-Mann-Whitney test to compare dosage groups by baseline quartile and time point.

blood cell folate levels for other quartiles showed similar patterns, although the change from baseline to final levels was smaller. Subjects who received $1 \mathrm{mg} / \mathrm{d}$ consistently showed significantly higher increases across all quartiles compared with those receiving $5 \mathrm{mg}$ /week.

Serum and red blood cell folate levels during the supplementation period did not vary by age and education level (data not shown). However, when we stratified serum folate levels by dosage group, BMI and time (Table 4), we observed significant increases in serum folate levels in dosage group and time for each category of BMI. Serum folate levels were significantly different between dosages only among those women with BMI $<$ $30 \mathrm{~kg} / \mathrm{m}^{2}$. Similar trends were observed in red blood cell folate levels between dosage groups and time but no significant differences within BMI groups.

\section{Discussion}

The results of the present randomized clinical trial indicate that both the daily and the weekly folic acid supplementation regimens significantly increased serum and red blood cell folate levels among the women studied. However, supplementation with a daily dose of $1 \mathrm{mg}$ led to a larger and more rapid increase in both serum and red blood cell folate levels from baseline to endpoint.

The increases and patterns attained in serum and red blood cell folate by both folic acid dosage regimens in the present trial are in line with previous studies ${ }^{(22-24)}$, but direct comparisons on absolute values cannot be made because of differences in laboratory procedures. However, in 2001 Martinez et al. ${ }^{(23)}$ carried out a supplementation trial with a weekly dosage of $5 \mathrm{mg}$ folic acid among non-pregnant women of childbearing age in Nuevo León, Mexico, using similar laboratory tests. These authors found after 12 weeks that serum and red blood cell folate levels increased from 5.93 to $7 \cdot 0 \mathrm{ng} / \mathrm{ml}(18 \%)$ and from $150 \cdot 5$ to $184 \cdot 0 \mathrm{ng} / \mathrm{ml}(22 \%)$, respectively. These absolute and relative increases in folate levels were significantly lower than those attained in our study. Some of these differences could be explained by smaller attrition and better compliance in our study.

Comparison of blood folate levels observed in the present study with other cross-sectional studies at prefortification and post-fortification levels are important 
Table 4 Serum folate and red blood cell folate levels of study participants by folic acid dosage group, BMI and time: Honduras, 2005

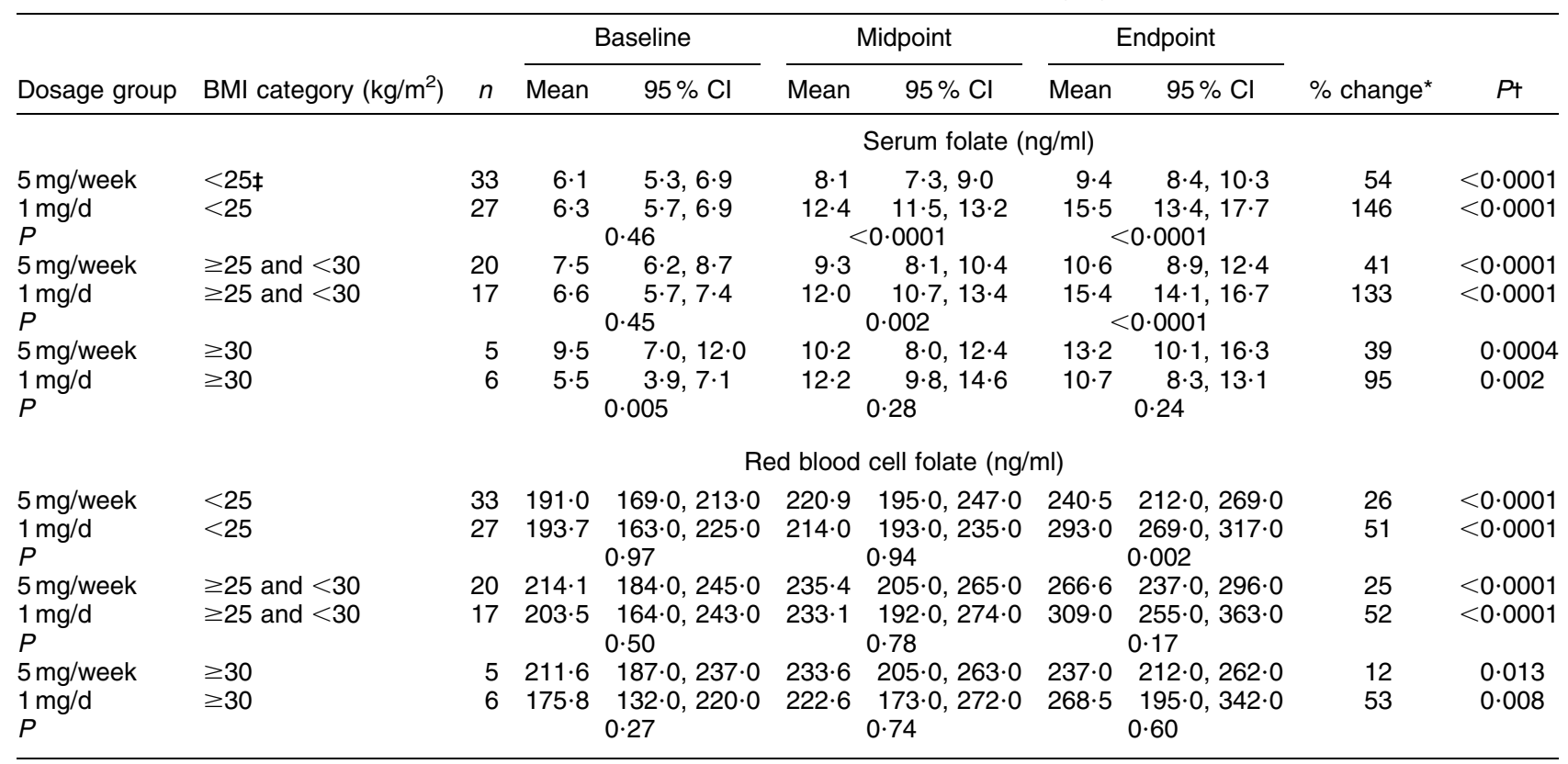

${ }^{*}$ Percentage increase from baseline to endpoint.

tTest for trend.

$\ddagger \mathrm{BMI}<25 \mathrm{~kg} / \mathrm{m}^{2}$, normal weight; $\mathrm{BMI} \geq 25$ and $<30 \mathrm{~kg} / \mathrm{m}^{2}$, overweight; $\mathrm{BMI} \geq 30 \mathrm{~kg} / \mathrm{m}^{2}$, obese.

because they can provide guidance on how populations or subgroups of populations are standing compared with other groups or populations that have reached higher folate levels. The baseline results from our study were similar to reported folate levels in a sample of volunteers among non-pregnant Honduran women ${ }^{(24)}$. However, mean baseline serum folate levels in our study were significantly higher than pre-fortification levels of US non-pregnant women of childbearing age studied in the 1994 NHANES (National Health and Nutrition Examination Survey) $(6.9 \text { and } 6.3 v .4 .6 \mathrm{ng} / \mathrm{ml}, P<0 \cdot 01)^{(25)}$. Serum folate levels after 6 weeks of intervention in our study subjects receiving a daily folic acid supplement of $1 \mathrm{mg}$ were similar to those found in 1999-2000 NHANES nonpregnant women after fortification $(12 \cdot 2 v .12 \cdot 6 \mathrm{ng} / \mathrm{ml})^{(26)}$. Furthermore, by the 12th week of intervention, serum folate levels were significantly higher in our study subjects $(14.9 v .12 .6 \mathrm{ng} / \mathrm{ml}, P<0.001)$ than in 1999-2000 NHANES. In contrast, among women receiving a weekly $5 \mathrm{mg}$ dose, mean serum folate levels were significantly lower than in NHANES non-pregnant women post-fortification $(8 \cdot 7$ and $10 \cdot 1$ v. $12 \cdot 6 \mathrm{ng} / \mathrm{ml}, P<0 \cdot 001)$.

Comparison of red blood cell folate levels at the end of 12 weeks showed that levels in NHANES non-pregnant women of childbearing age after folic acid fortification were similar to those observed in women receiving a weekly folic acid dose of $5 \mathrm{mg}$ in our study $(253 \cdot 3 v \cdot 250 \cdot 8 \mathrm{ng} / \mathrm{ml}, P=\mathrm{NS})$. In contrast, women receiving a daily supplementation dose of $1 \mathrm{mg}$ reached significantly higher red blood cell folate levels than NHANES women post-fortification (294.4 $v$. $253.3 \mathrm{ng} / \mathrm{ml}, P<0.01$ ) and were above the Healthy People 2010 target objectives $(220 \mathrm{ng} / \mathrm{ml})^{(27)}$. In addition, our data showed that women below the 25th percentile of baseline serum and red blood cell folate were the ones who benefited the most from the intervention.

Also, our study does not support the association of obesity with low serum and red blood cell folate levels ${ }^{(28)}$. The percentage increase in blood levels attained in both intervention groups was similar among all BMI groups. This is noteworthy, as obese women have been shown to have lower folate levels ${ }^{(29,30)}$.

The present study was a double-blind, randomized clinical trial with a high degree of regimen adherence and supervision. Our method of determining serum and red blood cell folate levels was carried out by the same laboratory that assessed folate levels for NHANES, ensuring comparability of the methods with other populations. The drop-out rates among supplementation groups ranging from $18 \%$ to $30 \%$ could have introduced some bias, but we believe it was minimal because the baseline characteristics of drop-outs and participants were similar in all aspects. Furthermore, in the majority of cases the cause for dropping out was not linked to the trial per se. Therefore, folate levels may not have been overestimated for participating women.

Important limitations of the present study were: (i) the two groups had different time lags between last pill taken and blood draw, which could have biased the group receiving the daily dosage to observed higher levels in serum and red blood cell folate; (ii) we were not able to observe the long-term effect of the two dosage regimens as the intervention and measurement of folic acid levels spanned only 12 weeks; and (iii) we did not assess the unmetabolized folic acid in serum ${ }^{(31,32)}$ nor the dietary 
intake of the participants. Recent research has demonstrated that, with higher dosages of folic acid, one can expect amounts of unmetabolized folic acid to be found in blood. Our study was not designed to evaluate unmetabolized folic acid.

The results of the present study are a first step helping the Honduran government to revise the current folic acid supplementation policy to provide women of childbearing age with enough folic acid to ensure adequate levels of folate before and during pregnancy. In a country where the underemployment rate is $29.6 \%$ and $69.5 \%$ of the population lives in poverty ${ }^{(33)}$, lack of access to processed foods prevents the impact that food fortification has had in other countries ${ }^{(5,33-36)}$. For these reasons Honduras would benefit more from the implementation of a cost-effective preconceptional folic acid supplementation programme that would reach the poor urban and rural high-risk populations. Recently, the regional office of the WHO in South Asia (Philippines, Cambodia and Vietnam) published results on community trials assessing the effectiveness of micronutrient supplementation to the population with a pill containing both $\mathrm{Fe}$ and folic $\operatorname{acid}^{(37-42)}$. The strategy tailored the supplementation intervention and market strategy to each country's culture and values. The adherence to weekly and daily pill use was high; however, while changes were observed in Fe measurements, changes in folate levels were not provided. These studies suggest that before embracing country-wide supplementation programmes it is important to evaluate the marketing strategies, the type of supplementation programmes and the cost-effectiveness of the interventions.

In our study, a daily dose of $1 \mathrm{mg}$ folic acid quickly elevated blood folate to levels that are believed to be protective against $\mathrm{NTD}^{(15)}$. While the blood folate levels of women consuming $5 \mathrm{mg}$ weekly did attain levels in keeping with the Healthy People 2010 for red blood cell folate, the protective effect of folic acid in the prevention of NTD has been demonstrated previously. Therefore, if pre- and periconceptional folic acid use nears 100\% and reaches high blood folate levels, we could expect a substantial decrease in the number of NTD cases. Establishing an NTD surveillance system coupled with periodic monitoring of blood folate could assess the impact from supplementation. Therefore, it is important that all women are made aware of the importance of periconceptional folic acid and that all women of reproductive age are taking it daily. Fortification of flour in Honduras has been in place since 2003. However, despite being an effective way of increasing folate intake, the penetration of this fortified food among high-risk populations remains very low because people do not have access to fortified products. Therefore, any national health policy strategy will require a combination of approaches including periconceptional supplementation with folic acid and fortification of staples, coupled with the promotion of vitamin use and monitoring of food fortification and levels of serum and red blood cell folate in the target population, and the establishment of a surveillance system to monitor the impact of these interventions on the prevalence of NTD.

\section{Acknowledgments}

Disclaimer: The findings and conclusions in the present report are those of the authors and do not necessarily represent the views of the Centers for Disease Control and Prevention.

Acknowledgements: We would like to thank the following groups and institutions: the working women for volunteering to participate in this study; the Grupo Kattan in Choloma, Honduras for allowing their employees to participate, providing the study site and serving as liaison to the Cooperative Folic Acid Research Group; the Honduran Ministry of Health for their cooperation and support; NOW Foods for the donation of folic acid tablets for the study; CURN - Centro Universitario de Región Norte, San Pedro Sula, Honduras for helping in the surveys and $\mathrm{Hb}$ blood draw; and Project Healthy Children, Weston, Massachusetts for providing funding for this project.

Authorship criteria and responsibility: We certify that all authors participated sufficiently in the work to take public responsibility for the content. We certify that we have: (i) made substantial contributions to the conception and design or analysis and interpretation of data; (ii) made substantial contributions to drafting the article or revising it critically for important intellectual content; and (iii) received approval of this version of the article submitted for review. We certify that the manuscript represents valid work, and neither this manuscript nor one with substantially similar content under our authorship has been published or is being considered for publication elsewhere. We attest that, if requested by the editors, we will provide the data or will cooperate fully in obtaining and providing the data on which the manuscript is based for examination by the editors and their assignees.

Financial disclosure: We certify that all our affiliations or financial involvement with any organization or entity with financial interest or a financial conflict with the subject matter or materials discussed in the manuscript are completely disclosed. We certify that all financial and material support for this research and work are clearly identified in the manuscript. We attest that, if requested by the editors, we will provide the data or will cooperate fully in obtaining and providing the data on which the manuscript is based for examination by the editors and their assignees.

\section{References}

1. Petrini J, Damus K \& Johnston RB (1997) An overview of infant mortality and birth defects in the United States. Teratology 56, 8-10. 
2. Kalien B, Robert E \& Harris J (1998) Associated malformations in infants and fetuses with upper or lower neural tube defects. Teratology 57, 56-63.

3. Lee K, Khoshnood B, Chen L, Wall SN, Cromie WJ \& Mittendorf RL (2001) Infant mortality from congenital malformations in the United States, 1970-1997. Obstet Gynecol 98, 620-627.

4. Botto L, Moore CA, Khoury MJ \& Erickson JD (2005) Neural tube defects. N Engl J Med 341, 1509-1519.

5. Chen LT \& Rivera MA (2004) The Costa Rican experience: reduction of neural tube defects following food fortification programs. Nutr Rev 62, S40-S43.

6. Institute of Nutrition of Central America and Panama (2005) I Taller Centroamericano de la Prevencion de Defectos del Nacimiento. Costa Rica: INCAP.

7. Milla G, Umaña E \& Mayes I (2002) Reporte de la Prevalencia Hospitalaria de Malformaciones Congenitas en Honduras. Honduras: Proyecto de Niños Saludables.

8. Lopez-Romero GG \& Mayes I (2004) Incidencia de anomalies congenitas y sus factores de riesgo diagnosticadas en el Instituto Hondureño de Seguridad Social durante el periodo Julio 2002 a Septiembre 2004. Presented at X Congreso de Postgraduados de Medicina UNAH-MSP-IHSS, Tegucigalpa, Honduras, 18-20 November 2004.

9. MRC Vitamin Study Research Group (1992) Prevention of neural tube defects: results of the Medical Research Council Vitamin Study. MRC Vitamin Study Research Group. Lancet 338, 131-137.

10. Czeizel AE \& Dudas I (1992) Prevention of the first occurrence of neural-tube defects by periconceptional vitamin supplementation. $N$ Engl J Med 327, 1832-1835.

11. Shaw GM, Schaffer D, Velie EM, Morland K \& Harris JA (1995) Periconceptional vitamin use, dietary folate, and the occurrence of neural tube defects. Epidemiology $\mathbf{6}$, 219-226.

12. Berry RJ, Li Z, Erickson JD et al. (1999) Prevention of neural-tube defects with folic acid in China. China-US Collaborative Project for Neural Tube Defect Prevention. N Engl J Med 341, 1485-1490.

13. Daly LE, Kirke PN, Molloy A, Weir DG \& Scott JM (1995) Folate levels and neural tube defects. Implications for prevention. JAMA 274, 1698-1702.

14. Wald N \& Hackshaw A (1997) Folic acid and prevention of neural-tube defects. Lancet 350, 665.

15. Wald NJ, Law MR, Morris JK \& Wald DS (2001) Quantifying the effect of folic acid. Lancet 358, 2069-2073.

16. Comision de Ministros de Economia de Centroamérica (2002) Reglamento Tecnico de la Union Aduanera Centroamericana. XXIV; R-UAC 67.01.15:12.

17. Milla GR, Flores AL, Umaña E, Mayes I \& Rosenthal J (2007) Knowledge, attitudes and practices of Honduran postpregnancy women. Rev Panam Salud Publica 22, 340-347.

18. Instituto de Estadistica de Honduras (2001) Censo de Poblacion de Gobernacion y Justicia del año 2001. http:// ccp.ucr.ac.cr/bup/honduras (accessed May 2006).

19. SAS Institute, Inc. (1999) SAS/STAT User Guide, Version 8. Cary, NC: SAS Institute, Inc.

20. Centers for Disease Control and Prevention (not dated) Folate/Vitamin B12 in Serum and Whole Blood - NHANES 2001-2002. Laboratory Procedure Manual. http://www. cdc.gov/nchs/data/nhanes/nhanes_01_02/106_b_met_folate_ B12.pdf (accessed January 2005).

21. Khattree R \& Naik DN (1999) Applied Multivariate Statistics with SAS Software, 2nd ed. Cary, NC: SAS Institute, Inc.

22. Norsworthy B, Skeaff CM, Adank C \& Green TJ (2004) Effects of once-a-week or daily folic acid supplementation on red blood cell folate concentrations in women. Eur J Clin Nutr 58, 548-554.

23. Martinez-de Villarreal L, Limon-Benavides C, Valdez-Leal R, Sanchez-Pena MA \& Villarreal JZ (2001) Impact of weekly administration of folic acid on folic acid blood levels. Salud Publica Mex 43, 103-107.

24. Holden KR, Collins JS, Greene JF, Hinkle S, Nave AF, Portillo JM, Page GP \& Stevenson RE; Honduran Neural Tube Defect Project Team (2002) Dietary intake and blood folate levels in Honduran women of childbearing age. J Child Neurol 17, 341-346.

25. Ganji V \& Kafai MR (2006) Trends in serum folate, RBC folate, and circulating total homocysteine concentrations in the United States: analysis from National Health and Nutrition Examination Surveys, 1988-1994, 1999-2000, and 2001-2002. J Nutr 136, 153-158.

26. Pfeiffer CM, Caudill SP, Gunter EW, Osterloh J \& Sampson EJ (2005) Biochemical indicators of B vitamin status in the US population after folic acid fortification: results from the National Health and Nutrition Examination Survey 1999-2000. Am J Clin Nutr 82, 442-450.

27. Healthy People 2010 (2001) Objectives for improving health: 16. Increase the proportion of pregnancies begun with an optimum folic acid level. http://www. healthypeople.gov/document/tableofcontents.htm\#parta (accessed May 2006).

28. Casanueva E, Pfeffer F, Drijanski A, Fernandez-Gaxiola AC, Gutierrez-Valenzuela V \& Rothenberg SJ (2003) Iron and folate status before pregnancy and anemia during pregnancy. Ann Nutr Metab 47, 60-63.

29. Mojtalbi R (2004) Body mass index and serum folate in childbearing age women. Eur J Epidemiol 19, 1029-1036.

30. Watkins ML, Scanlon KS, Mulinare J \& Khoury MJ (1996) Is maternal obesity a risk factor for anencephaly and spina bifida? Epidemiology 7, 507-512.

31. Sweeney MR, McPartlin J \& Scott J (2007) Folic acid fortification and public health: report on threshold doses above which unmetabolised folic acid appear in serum. BMC Public Health 7, 41-47.

32. Kelly P, McPartlin J, Goggins M, Weir DG \& Scott JM (1997) Unmetabolized folic acid in serum: acute studies in subjects consuming fortified food and supplements. Am J Clin Nutr 65, 1790-1795.

33. Secretaria de Salud (2004) Situacion de Salud en Honduras. Indicadores Básicos, 2004. Tegucigalpa, Honduras: Secretaria de Salud.

34. Hertrampf E, Cortes F, Erickson JD, Cayazzo M, Freire W, Bailey LB, Howson C, Kauwell GP \& Pfeiffer C (2003) Consumption of folic acid-fortified bread improves folate status in women of reproductive age in Chile. J Nutr $\mathbf{1 3 3}$, 3166-3169.

35. Feinleib M, Beresford SA, Bowman BA, Mills JL, Rader JI, Selhub J \& Yetley EA (2001) Folate fortification for the prevention of birth defects: case study. Am J Epidemiol 154, S60-S69.

36. Martínez de Villarreal L, Pérez JZ, Vázquez PA et al. (2002) Decline of neural tube defects cases after a folic acid campaign in Nuevo León, México. Teratology 66, 249-256.

37. Berger J, Thanh HT, Cavalli-Sforza T, Smitasiri S, Khan NC, Milani S, Hoa PT, Quang ND \& Viteri F (2005) Community mobilization and social marketing to promote weekly iron-folic acid supplementation in women of reproductive age in Vietnam: impact on anemia and iron status. Nutr Rev 63, S95-S108.

38. Paulino LS, Angeles-Agdeppa I, Etorma UM, Ramos AC \& Cavalli-Sforza T (2005) Weekly iron-folic acid supplementation to improve iron status and prevent pregnancy anemia in Filipino women of reproductive age: the Philippine experience through government and private partnership. Nutr Rev 63, S109-S115.

39. Angeles-Agdeppa I, Paulino LS, Ramos AC, Etorma UM, Cavalli-Sforza T \& Milani S (2005) Government-industry partnership in weekly iron-folic acid supplementation for 
women of reproductive age in the Philippines: impact on iron status. Nutr Rev 63, S116-S125.

40. Kanal K, Busch-Hallen J, Cavalli-Sforza T, Crape B \& Smitasiri S; Cambodian Weekly Iron-Folic Acid Program Team (2005) Weekly iron-folic acid supplements to prevent anemia among Cambodian women in three settings: process and outcomes of social marketing and community mobilization. Nutr Rev 63, S126-S133.
41. Longfils P, Heang UK, Soeng H \& Sinuon M (2005) Weekly iron and folic acid supplementation as a tool to reduce anemia among primary school children in Cambodia. Nutr Rev 63, S139-S145.

42. Garcia J, Datol-Barret E \& Dizon M (2005) Industry experience in promoting weekly iron-folic acid supplementation in the Philippines. Nutr Rev 63, S146-S151. 